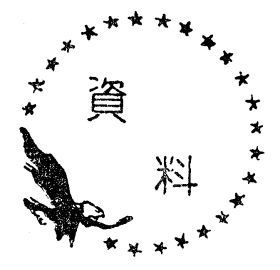

\section{I . 緒訔}

石炭の構造を究明する手段として，また石炭の有効 利用の目的で石炭の酸化はすでに長い歴史を有して いる。近年石炭の酸化生成物から得られるいわゆる “coal acid” が熱硬化性樹脂, 水溶性フィルム, 泥漿希 䣋剤などの特異な原料として認められ, 石炭酸化は石 炭化学の一環としてますます重要性を高めつつある。

石炭の酸化は乾式と湿式に大きくわけられるが, 乾 式酸化からはもつぱらフミン酸が得られ, 酸化機構の 解明あるいはさらに低分子の酸を得るための予備処理 に利用される1)。湿式酸化は比較的低分子の芳香族酸 の製造に応用され，硝酸酸化とアルカリ溶液中での酸 化の 2 種類が主である。アルカリ溶液意使用して石炭 を酸化すると, 有機酸の生成がすみやかに進行し，ま た有機酸が安定に保たれるために有機酸を選択的に生 成しうる利があり，この種の研究では Fischer ${ }^{22}$, Bone $^{3)}$ に続いて Howard ${ }^{4) 5)}$, Simsic ${ }^{6)}$ の詳細な報 告がある。神谷氏78) も本邦炭について系統的な研究 を行なつている。石炭を酸化して得られる生成物の分 離についても広汎な研究がなされ，前記の諸氏のほか に Montgomery ${ }^{9)}$, Jüttner ${ }^{10)}$, Grosskinsky ${ }^{11)} ら$ もそれぞれ分析法を報告している。

筆者はベンゼンポリカルボン酸孛利用研究する目的 から，その原料として台湾の石崖を用いてアルカリ溶
U. D. C. $662.743: 66.094 .7$ (529). 1

カリ性酸化

一昭 和 37 年 7 月 20 日 受 理一

東京大学工学部 石栄煒

液中で酸素による酸化反応を行ない，その生成物の分

析を試みた。

\section{II. 実 験 方 法}

1) 酸化反応

i）陚料 アルカリ水溶液中での酸化には高炭化度 瀝青炭が水可溶酸の収率の点でもつとも良好であるた め, 台湾産の石炭の中もつとも適格と思われる新竹南 庄炭を採用した。試料は $80 \mathrm{mesh}$ 通過のものを使つた がその工業分析值は

$$
\begin{array}{rrrr}
\text { 水 分 } 1.0 \% & \text { 灰 分 } & 7.1 \% \\
\text { 揮 発 分 } 24.8 \% & \text { 固定炭素 } & 67.2 \%
\end{array}
$$

であり，無水無灰ベースでの元素組成は

$$
\text { 炭素 } 88.9 \% \text { 水 素 } 4.7 \%
$$

であつた。

ii） 反応操作, 反応装置は内容積 $3 l$ のステンレス 電磁上下攪拌式オートクレーブ7を用いた。それに $100 \mathrm{~g}$ 炭素相当の石炭試料と, 酸化で生成する有機酸 と炭酸ガスの中和㧍よび吸収に充分の量である $400 \mathrm{~g}$ の苛性ソーダを $1.5 l$ の水溶液にしたもの（約 $6.5 \mathrm{~N}$ $\mathrm{NaOH}$ 溶液) を入れ, 温度, 酸素圧, 反応時間ならび に攪拌速度を変えて実験を行なつた。

2) 酸化生成物の分析

i） 反応生成液について分析法の概略を示すと第 1 四のごとくである8)。

第1図反応生成液分析概略

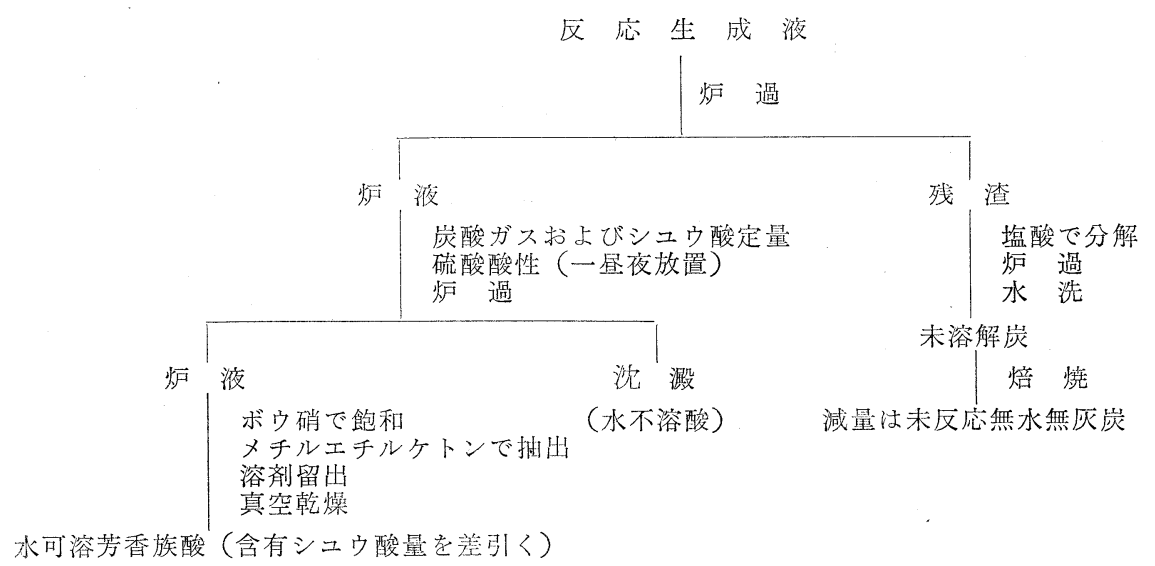


ii）水可溶酸について上述の方法に上り分離した 水可溶酸はメタノールでエステル化した後, 真空分別 蒸留した。各留分についてはェステルの状態あるいは ケン化して酸の状態汇戾し, 沈洪法, 溶郕分別法 (向
流分配）および再結晶法，赤外分析などを利用して定 量および確認を行なつた。第 2 図にエステル化の概略 を示した。

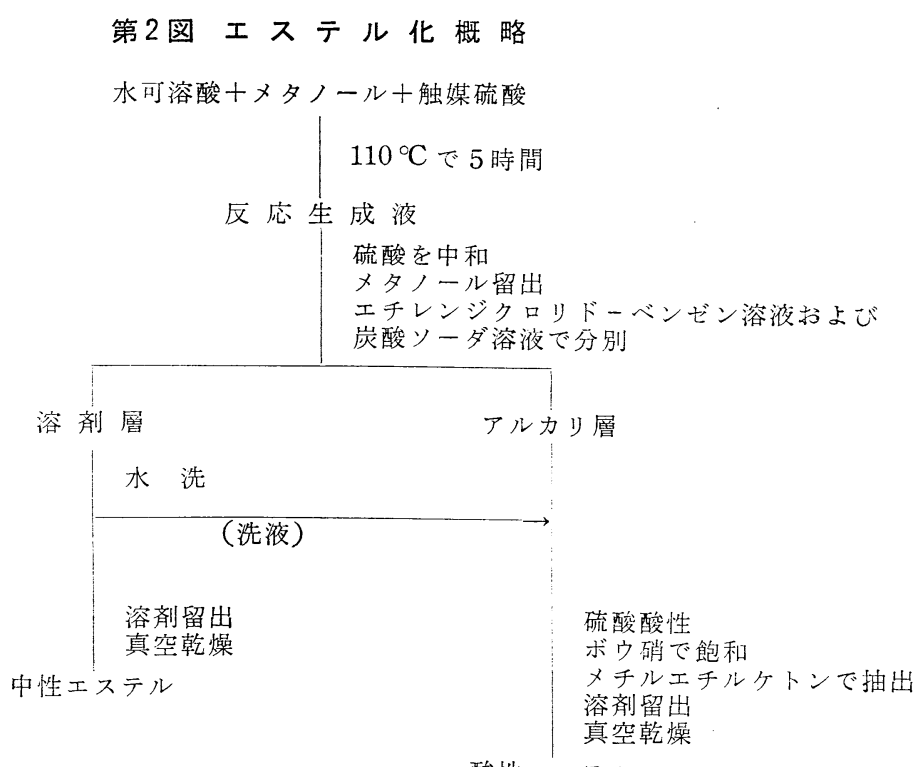

酸性エステル

（繰返しェステル化）

\section{III. 実 験 結 果}

1) 酸化条件と生成物の関係

石炭を酸化して得られる水可溶酸や水不溶酸は，以 わば石炭の酸化過程における中間生成物であるから， その収率洼䚵石炭の種類と酸化の条件によつてこと なる。

第 $3,4,5,6$ 図结縦軸记酸化生成物の収率をとり， 横蚰にそれ态れ温度, 反応圧力, 反応時間, および㩭 拌速度をとつて, 各反応条件と生成物収率の関係を図

\section{第3 図反応温度の影響}

(その他の反応条件 : 反応圧力 $\left.60 \mathrm{~kg} / \mathrm{cm}^{2}\right)$

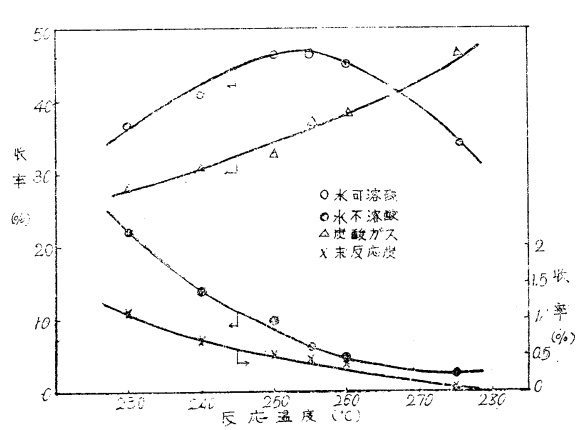

示したものである。生成物の収率はいずれも各含有炭 素の試料炭素に対する百分率で表わした。シュウ酸の 收率は平均して数\%であつたが, 反応生成液のアルカ リ濃度に敏感であり, 定量が不完全であつたため表示 しなかつた。石炭の酸化生成物として注その他にごく 少量の蟻酸, 酶酸, プロピオン酸などの低分子脂肪族

\section{第4图反店圧力の影響}

(その他の反応条件 : 反応温度 $255^{\circ} \mathrm{C}$, $)$

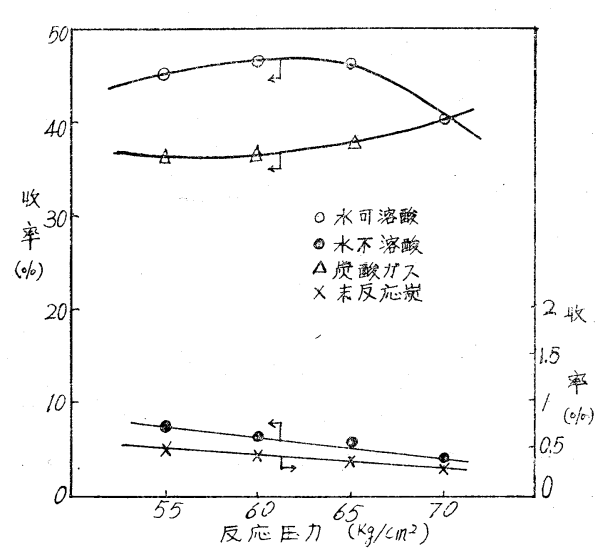


第 5 図 反応時間 の影響

その他の反応条件 : 反応温度 $255^{\circ} \mathrm{C}$, 反応圧力 $60 \mathrm{~kg} / \mathrm{cm}^{2}$, 擋拌速度 70 times $/ \mathrm{min}$ )

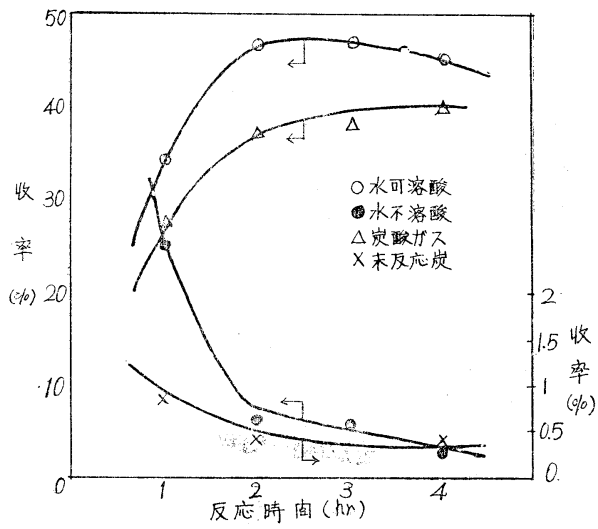

第 6 図 㩭 拌速度 の 影響

$\left.\begin{array}{l}\text { (气の他の反応条件 : 反応温度 } 225^{\circ} \mathrm{C}, \\ \text { 反応圧力 } 60 \mathrm{~kg} / \mathrm{cm}^{2} \text {, 反応時間 } 1 \mathrm{hr}\end{array}\right)$

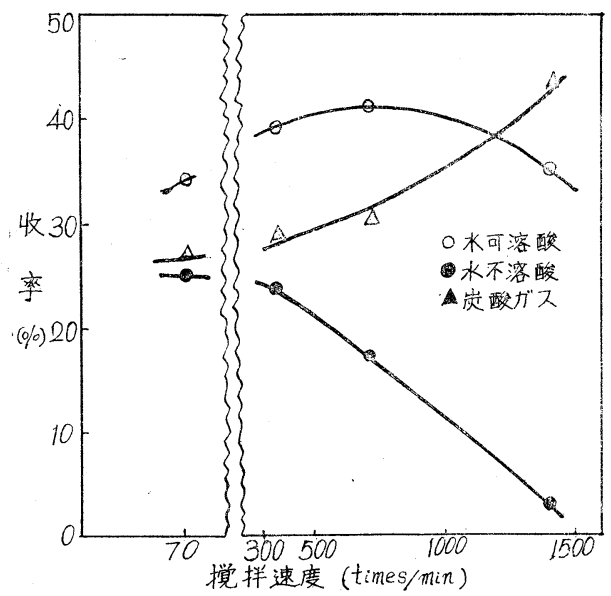

酸もあるが, 反応生成液の収集および分析操作中に逸 散しやすく, 定量しなかつた。全生成物の炭素回収率 は94 97\%であつた。

これらの図をみると，与えられた条件下で，反応温 度は $250 \sim 260^{\circ} \mathrm{C}$ が最高の水可溶酸収率を示し, 反応 圧力はこの範囲内ではいちじるしい影響を現わさなか つた。反応時間は 2 時間で大体十分であり，それ以上 反応時間が長くなると反応がやや進行しても水可溶酸 の収率はたいしてかわらなかつた。第 6 図の㩭拌効果 は，攪拌数 70 times $/ \mathrm{min}$ のもの以外は $0.5 l$ のオー トクレーブに前者の場合に比例して試料を入れ，プロ ペラ式㩖拌で反応を行なつた場合の数值であるが，こ の範囲内の条件下では，㩭拌速度を変えることによつ
て反応時間をかなり短縮し得ることがあきらかであつ た。以上の結果よりみて, この種の酸化反応の工業化 に際しては反応装置の構造が反応条件を左右する重要 な要素であることがわかつた。

第 7 図に炭酸ガスの生成率と水可溶酸および水不溶 酸の収率の関係を示したが，アルカリ量が適当であれ ばこの範囲内の条件下では, 酸化度と収率の間に一定 の関連があることを認めた。

第7図 酸化度と収率の関係

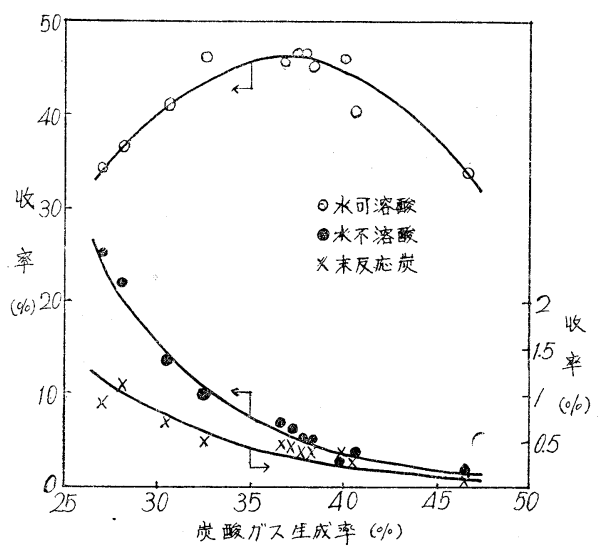

これらの実験を通じて, 水可溶酸の最高収率は試料 無水無兏炭に対して重量で $82.2 \%$ であつた。

第 1 表と第 2 表におのおの水可溶酸の最高収率の場 合の反応条件と炭素分布を示し, 水可溶酸と水不溶酸 の諸性質を第 3 表にまとめた。

\section{第 1 表 最高収率の反応条件}

石 炭 $122.5 \mathrm{~g}(100 \mathrm{~g}$ 炭素 $) \mid$ 温 度 $255^{\circ} \mathrm{C}$ 水 $1.5 \mathrm{l}$ 反応压力 $60 \mathrm{~kg} / \mathrm{cm}^{2}$ 苛性ソーダ $400 \mathrm{~g}$ 時 間 $2 \mathrm{hr}$

反応容積 $3 l$ 㩭 拌 70 times $/ \mathrm{min}$

\section{第 2 表 最高収率の炭素分布}

\begin{tabular}{cc} 
生成物 & 炭素の\% \\
水可溶酸 & 46.5 \\
水不溶 酸 & 6.2 \\
シ こ ウ 酸 & 6.5 \\
炭酸 ガ & 37.1 \\
末 反応炭 & 0.5 \\
\hline
\end{tabular}




\section{第 3 表 最高収率の水可溶酸と水不溶酸の性質}

$\begin{array}{ccc}\text { 性質 } & \begin{array}{c}\text { 水可溶酸 } \\ \text { 色 }\end{array} & \begin{array}{c}\text { 水不溶酸 } \\ \text { 黄 褐 色 }\end{array} \\ \text { 炭素(\%) } & 50.9 & 60.1 \\ \text { 水素(\%) } & 3.9 & 3.7 \\ \text { 分子 量 } & 268 & - \\ \text { 中和当量 } & 83 & 134\end{array}$

2) 水可溶酸の分析

i）エステル化および真空分留

上述の反応条件で得た承可溶酸 $185 \mathrm{~g}$, メタノール $500 \mathrm{~g}$, 濃硫酸 $25 \mathrm{cc}$ を内容積 $1 l$ のステンレス製オー
トクレーブにて加圧エステル化を5回繰返して行ない， 中性エステル $175 \mathrm{~g}$ と酸性エステル $8 \mathrm{~g}$, ほかに少量 の不溶性エステルを得た。つぎに中性エステル $170 \mathrm{~g}$ を固体試料用真空蒸留装置 (内径 $1.0 \mathrm{~cm}$, 長さ $26 \mathrm{~cm}$, ディクソンパッキング充填) を用いて，真空度 3.0 $8.0 \mathrm{mmHg}$, 留出温度 $120 \sim 230^{\circ} \mathrm{C}$ の範国で分留を行 ない, 留出物を 4 つの部分にわけた（第 4 表, F-1 ～4)。分留残留物はさらにベンゼンを傎つて者沸抽 出を行ない。ベンゼン可溶分 $19.5 \mathrm{~g}$ を得た。それを八 ウベンフラスコにとり，1 $\mathrm{mmHg}, \sim 250^{\circ} \mathrm{C}$ で真空蒸 留を行なつて最終留出物を得た（第 4 表，F-5)。総留 出量は $88.5 \mathrm{~g}$ で試料エステルの $52 \%$ に当り, 分解ガ

\section{第4表エステルの䢙空分留結果}

$\begin{array}{lcc}\text { 留 } \quad \text { 分 } & \text { 留出温度 }\left({ }^{\circ} \mathrm{C}\right) & \text { 真空度 }(\mathrm{mmHg}) \\ \mathrm{F}-1 & 120 \sim 133 & 3 \\ \mathrm{~F}-2 & 133 \sim 190 & 3 \\ \mathrm{~F}-3 & 190 \sim 215 & 5 \\ \mathrm{~F}-4 & 215 \sim 230 & 8 \\ \mathrm{~F}-5 & 250 & 1 \\ \text { 残 渣 } & & \end{array}$

\begin{tabular}{ll}
\multicolumn{1}{c}{ 性 } & 状 \\
淡黄色，無色針状結晶 & 13.6 \\
黄色液，白色結晶 & 21.5 \\
黄白色固体 & 15.9 \\
黄白色固体 & 29.6 \\
橙色粘ちよう物 & 7.9 \\
& 56.2
\end{tabular}

第 8 図 フタル酸成分の向流分配図

スなどによる損失は $25.3 \mathrm{~g}$ (14.9\%) に達した。

ii）各留分中の酸の定量確認

F-1の分析 無色釬状結晶が $0.576 \mathrm{~g}$ 晶出した が, 融点を測定してテレフタル酸メチルエステルを確 認した。液状成分 $2.090 \mathrm{~g}$ を $2 \mathrm{NHCl}$ 溶液で 24 時間 還流してケン化した後乾固し, $40^{\circ} \mathrm{C}$ の水 $200 \mathrm{cc}$ を加 えて不溶分としてイソフタル酸 $0.241 \mathrm{~g}$ を分離確認し た。可溶分注大部分が 0 - フタル酸であつたが，この 留分に含まれると思われたシュウ酸や安息香酸を調べ るために, さらに液状成分のケン化乾固物をエーテル 一水で向流分配を行なつた。結果は第 8 罒のごとくで あり，AとCの部分は向流分配係数 ${ }^{8)}$ からそれぞれシ ュウ酸と安息香酸を主成分とするものと察せられた。 $\mathrm{B}$ の部分は $72.9 \%$ を占め, 中和当量 (82.8 83.4) からもフタル酸と確認し得た。これらの值から F-1 留分中のフタル酸の含有量はつぎのとおりとなつた。

$$
\begin{array}{ll}
0 \text {-フタル酸 } & 6.3 \mathrm{~g} \\
\text { イソフタル酸 } & 1.5 \mathrm{~g} \\
\text { テレフタル酸 } & 0.5 \mathrm{~g}
\end{array}
$$

$\mathrm{F}-2$ の分析 結晶成分の赤外スペクトルは完全に ヘミメリット酸メチルエステル $(1,2,3)$ のものと 一致し（カッコ内は置換基の位置を示す）, 結晶成分 中にトリメシン酸メチルエステル $(1,3,5)$ が共存 しないことがわかつた。トリメシン酸メチルエステル

(エーテル $/$ 水 $=10 \mathrm{cc} / 10 \mathrm{cc}$, 操作回数 20 , )
充塡試料 $0.50 \mathrm{~g}$ )

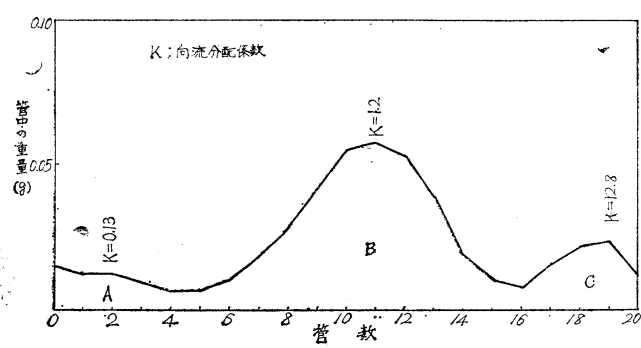

があるとすれば結晶中に含まれるはずであるから本留 分中にトリメシン酸メチルエステルがないことを示し ていた。本留分をケン化後乾固して得た酸成分を向流 分配して第 9 図の結果を得た。図中 $\mathrm{A}$ と B部分はそ れぞれ: $35.2 \%$ と $59.0 \%$ あつて, 中和当量は共に 70 \pm 2 であり, 分配係数からもおのおのへミメリット酸 (筆者による分配係数訂正值 0.13 ) とトリメリット酸 $(1,2,4)$ と考えられた。Cの部分は中和当量が 87 〜15 であつたが, 組成を解明できなかつた。向流分 配の值より，F-2 留分中のトリカルボン酸の含有量 はつぎのごとくになつた。

$$
\begin{array}{lr}
\text { トリメリット酸 } & 10.8 \mathrm{~g} \\
\text { ヘミメリット酸 } & 6.5 \mathrm{~g}
\end{array}
$$


第 9 図 ベンゼントリカルボン酸成分の向流分配図

(エーテル/水 $=10 \mathrm{cc} / 10 \mathrm{cc}$, 操作回数 20,
充填試料 $0.482 \mathrm{~g}$ )

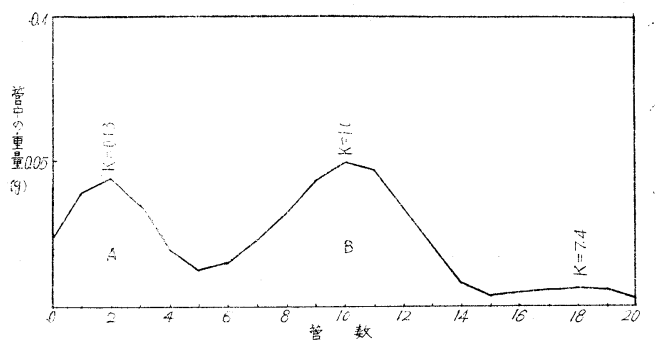

$\mathrm{F}-3$ の分析 この留分はベンゼンテトラカルボン 酸メチルエステルを主成分とするものであり, 各異性 体の定量は行なえなかつたが，アルコールを使つて再 結晶法により板状結晶（比較的多量）と粒状結晶を得 て融点測定ならびに赤外分析よりそれぞれピロメリッ 卜酸メチルエステル $(1,2,4,5)$ (比較的多量) と $1,2,3,4$-ベンゼンテトラカルボン酸メチルエス テルを確認した。また，晶出しなかつたものの主成分 は赤外分析によつて $1,2,3,5$-ベンゼンテトラカ ルボン酸メチルエステルと判明した。ベンゼンテトラ カルボン酸の全含有量を調ベるため, 本留分をケン化 後乾固した酸成分を向流分配して第10図の結 果を得 た。テトラカルボン酸は分配係数から図中のAの大部 分であり $(87.4 \%)$, 中和当量 $(63.5 \sim 64.2)$ からも それを判定し得た。Bの部分 (8.1\%) は中和当量が 68.5 73.0 であり，分配係数を参照してベンゼント リカルボン酸と判定した。その他少量の部分Cは水に 難溶でエーテルに易溶のものであつて, ベンゼンカル ボン酸ではないと推察された。向流分配の結果より， F - 3 留分注ベンゼンテトラカルボン酸を $11.3 \mathrm{~g}$, ベ ンゼントリカルボン酸を $1.0 \mathrm{~g}$ 含むことになつた。

第10図 ベンゼンテトラカルボン酸成分の 向流分配図 (1)

(エーテル/水 $=10 \mathrm{cc} / 10 \mathrm{cc}$, 操作回数 20,
充塡試料 $0.42 \mathrm{~g}$

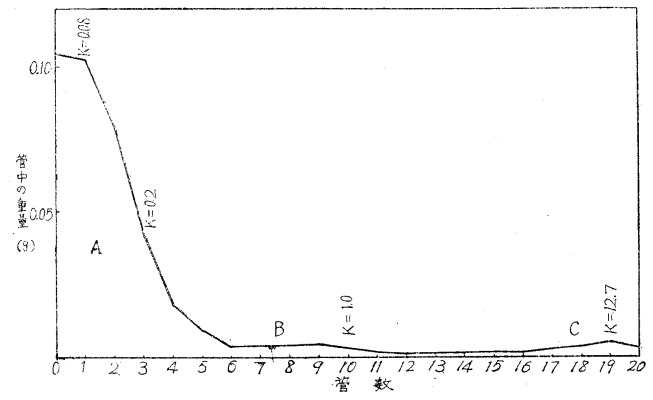

F-4の分析 F-3 留分と同様に, アルコール再 結晶と赤外分析により， $1,2,3,4$-ベンゼンテト ラカルボン酸メチルエステル（比較的多量）とピロメ リット酸メチルエステルならびに $1,2,3,5$-ベン ゼンテトラカルボン酸メチルエステルの存在を確認し た。ケン化して得た酸成分を向流分配した結果が第 11 図であり，図中 $\mathrm{A}$ の部分は分配係数と中和当量 (63.5 ～65.6) よりベンゼンテトラカルボン酸と推察でき, $67.5 \%$ を占めた。中間の部分 B (管数6 15) と Cの

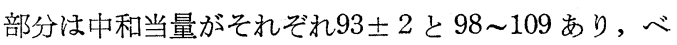
ンゼンカルボン酸以外のものと考えられた。すなわち $\mathrm{F}-4$ 留分は $17.8 \mathrm{~g}$ のベンゼンテトラカルボン酸を 含有した。

\section{第11図 ベンゼンテトラカルボン酸成分の 向流分配図 (2)}

エーテル $/$ 水 $=10 \mathrm{cc} / 10 \mathrm{cc}$, 操作回数 20,
充填試料 $0.50 \mathrm{~g}$ )

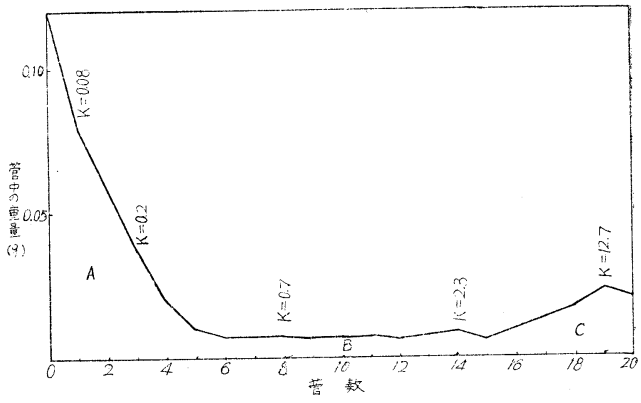

F-5の分析 ハウベンフラスコを使つて留出した 粘ちよら物をアルコールに溶解して, 長期間放置して も晶出をみなかつた。ナフタリン系やジフエニル系の ようなカルボン酸の混合物だと思われた。

酸性エステルの分析 水可溶酸をメタノールで 5 回 繰返して行なつたエステル化でな拉酸性エステルとな つて残つた部分は，多分にベンゼンペンタカルボン酸 やメリット酸 $(1,2,3,4,5,6)$ の不完全エステ ルを含むものと考えた。 $4.220 \mathrm{~g}$ の試料をケン化後メ チルエチルケトンで抽出して得た固体酸に濃アンモニ ア水を加えて白色沈洪，0.578g 省得た。沈澱を硝酸 で中和し，乾固して得たものはほとんどメリット酸で あり,アルコールから晶出した針状結晶を融点と赤外 分析より確認した。濃アンモニア水可溶分は硫酸酸性 にした後メチルエチルケトンで抽出して固体酸を回收 し，再度メタノールで繰返してェステル化して中性エ ステルを分離した。それをハウベンフラスコを使つて $3 \mathrm{mmHg}, 250^{\circ} \mathrm{C}$ で留出分を集め, アルコールから再 
結晶して板状結晶 $0.425 \mathrm{~g}$ を得た。これは融点と赤外 分析によつてペンタカルボン酸メチルエステルと認め た。すなうちさきの $8 \mathrm{~g}$ の酸性エステル中には $1.1 \mathrm{~g}$ のメリット酸と $0.8 \mathrm{~g}$ のベンゼンペンタカルボン酸を
含んでいた。

以上，台湾の南庄炭について行なつた酸化の結果を まとめ, 神谷氏の行なつた日本の鹿町炭の酸化結果と の比較を第 5 表に示した。この表より, 南庄炭は鹿町

第 5 表 鹿 町 炭と の 比較

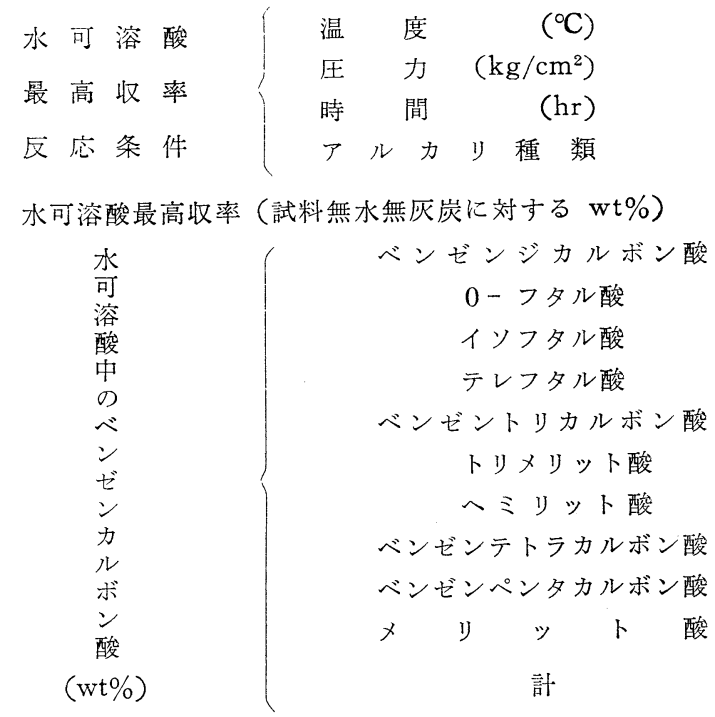

試料無水無灰炭に対するベンゼンカルボン酸の収率（wt $\%$ )

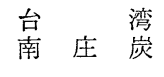

255

60

2

$\mathrm{NaOH}$

82.2

4.7
6.9

3.5

0.9

5.7

1.1

0.3

10.2

6.4

3.8

16.0

0.4

0.6

31.9

26.3

$$
\begin{array}{ccc}
\text { 日 } & \begin{array}{c}
\text { 本 } \\
\text { 鹿 }
\end{array} & \text { 町 } \begin{array}{c}
\text { 炭 } \\
2
\end{array} \\
270 \\
70 \\
2 \\
\mathrm{Na}_{2} \mathrm{CO}_{3}
\end{array}
$$

58 9
16.2

11.2

5.0

18. 3

2.9

0.3

44.6

26. 1
炭にくらべて酸化生成物の水可溶酸の収率が高かつた にもかかわらず, 水可溶酸からのベンゼンカルボン酸 の収率が低かつたために，結局試料炭に対するべンゼ ンカルボン酸収率はほとんど変らなかつた。

\section{IV. 結 論}

（1）台湾新竹産の南庄炭を苛性ソーダ溶液中で酸 素を使つて酸化を行ない, 反応温度 $255^{\circ} \mathrm{C}$, 反応压力 $60 \mathrm{~kg} / \mathrm{cm}^{2}$ で 2 時間反応した場合試料無水無灰炭に対 して $82.2 \%$ の高収率で水可溶酸を得た。

（2）この場合の水可溶酸をメチルエステルにして 分別蒸留し各留分について分析を行なつて, 試料宸に 対して $26.2 \%$ のベンゼンカルボン酸を得た。

（3）かよらな反応条件で生成した水可溶酸からの ベンゼンカルボン酸収率は低く，わずかに $31.9 \%$ で あつた。これは酸化度が低かつたために水可溶酸の中 に比較的高分子の酸を含むからだと考えられ，あるい は酸化度を高めることによつて水可溶酸の収率がやや 減つてもベンゼンカルボン酸の最終収率を高めうるか もしれない。
本研究の実施に際して与えられた安東新午教授と神 谷佳男講師の御援助に対して厚く感謝の意を表する。

\section{文献}

1) L. D. Friedman et al, Ind. Eng. Chem. 42, 2525 (1950)

2) F. Fischer et al, Abhandl. d. Kohle 4, 342; (1920) 5, 135 (1922)

3) W. A. Bone et al, Proc. Roy. Soc. (London) A110, 537 (1926); A127, 480 ; (1930) A148, 492 (1953)

4) H. C. Howard et al, J. Am. Chem. Soc. 61, 2398 (1939);73, 3873 (1951);74, 3239 (1952)

5) H. C. Howard et al, Ind. Eng. Chem. 44 2784. (1952)

6) J. B. Simsic et al Paper presented before the Division of Gas and Fuel Chemistry at the 125th meeting of the American Chemical Society, Kansas City, Mo., March 31, 1954

7) 神谷佳男, 工化, 59, 197 (1956)；60，246 (1957); 
61，197，337 (1958); 燃協誌，38，638 (1959)

8）神谷佳男, 工化，61，1169 (1958)；62, 106 (1959);

64, 2165 (1961)
47, 1274 (1955)

10) B. Jüttner, Brennstoff-Chem. 37, 70 (1956)

11) O. Grosskinsky et al, D. R. P. 936,568 (19 55); 937, 892 (1956); U.S.P. 2, 785, 198(1957)

9) R. S. Montgomery et al, Ind. Eng. Chem.

\title{
Studies on the Oxidation of a Taiwan Coal
}

\author{
by Shih Jung-Wei
}

(Tokyo University)

SYNOPSIS : - One of the typical bituminous coals of Taiwan, Nantswang coal, was subjected to oxygen-oxidation in alkaline slurries. The effects of the variables such as temperature, time, oxygen pressure and agitation velocity were studied to determine the conditions for the maximum yield of "water soluble" acids. An analysis was also made fer the product obtained under such conditions.

\section{正誤表}

Vol. 41, No. 428 1962年12月号 包蔵水分（水分保持容量）の測定

\begin{tabular}{|c|c|c|c|c|}
\hline 頁 & 欄 & 行 & 誤 & 正 \\
\hline 993 & 右 & $\uparrow 12$ & I 2 亜瀝 & I 2 無煙 \\
\hline$\prime \prime$ & $\prime \prime$ & $\uparrow 11$ & I 3 青無煙 & I 3 半無煙 \\
\hline 994 & $\prime \prime$ & $\downarrow 7$ & 直ちに & 直ちに縮 \\
\hline 995 & $\prime \prime$ & $\uparrow 24$ & $107 \mathrm{deg}$ & $107^{\circ} \mathrm{C}$ \\
\hline 997 & 表 & $\uparrow 3$ & (d. $\mathrm{m}^{\prime} . \mathrm{f}$. & (d. $\mathrm{m}^{\prime}$.f.) \\
\hline$\prime \prime$ & $\prime \prime$ & " & m.a.f. & (m.a.f.) \\
\hline 998 & " & "I & $\begin{array}{l}\text { 無灰, 恒湿, d. a. f., } \\
\text { m.a.f.にカッきをつる }\end{array}$ & d. m'. f. および \\
\hline 1000 & 右 & $\downarrow 11$ & Gilbast & Gilbart \\
\hline
\end{tabular}

